\title{
Beneficial Assessment of Water Pricing for Community Water Supply in Nigeria
}

\author{
N.S.M. Ogbonna, H.U. Nwoke, N.L. Nwakwasi \& B.U. Dike \\ Department of Civil Engineering, Federal University of Technology, Owerri, Nigeria, Africa. \\ DOI: $10.31364 / \mathrm{SCIRJ} / \mathrm{v} 8.13 .2020 . P 0320755$ \\ http://dx.doi.org/10.31364/SCIRJ/v8.i3.2020.P0320755
}

\begin{abstract}
Water supply has been a major challenge in most developing nations. Access to potable water in most Nigerian communities has posed a critical concern for both industrial and domestic efforts. Government water schemes have been inadequate and inefficient as well as unsustainable, which has led to the teeming population in the communities resorting heavily to other means of water supply, especially commercial boreholes. The pricing mechanism for these alternative water utilities has been largely unregulated leading to randomly fixed water prices. The objective was to devise an appropriate pricing model for community water supply which would be harmonized, engender water resource conservation and also achieve both social welfare and economic welfare maximizations. A survey was conducted, employing offline questionnaires. The target population was nine communities situated across the South-east and South-south geopolitical zones of Nigeria. The sample space was structured by age to be within seventeen to sixty-six years (17-66yrs) and a sample size of one hundred adopted. The survey tested and showed that pricing for water supply is influenced by age, gender, religion and other secondary factors besides economic power. A test quantity of twenty-five litres (25ltrs) was used from which corresponding one litre (1ltr) prices were obtained. Data was analyzed statistically for mean $(\mu)$, median $(\lambda)$, mode $(\varnothing)$ and standard deviation $(\sigma)$ of prices per litre of borehole water. An overall mean price of $\$ 0.4$ /litre and a standard deviation of $\$ 0.052$ were obtained for the sample. With the incorporation of a service or access charge factor for the borehole utility, an all-encompassing pricing model of $[p=0.4+z]$ was achieved for a litre of water. Being that the sample showed a normal distribution behaviour, the model is considered suitable for the entire target population. Also, based on informed basic assumptions made which are verifiable, this model can be extended to further cover other communities beyond the target population.
\end{abstract}

Keywords: Community; Pricing; model; Water Supply; Welfare maximization

\section{Introduction}

Besides being part of the three basic needs of man [6], water can be said to be one of the most essential natural resource on the planet earth [24]. Its broad applications in vast processes of life and human activities reinforce this age-long ideology [20]. Not only has water played an important role in the industrial revolutions and economic emancipation of evolving civilizations but also serves indispensably in common everyday domestic operations [2]. Coming to domestic purposes, the most resounding application of water is for drinking, which is primarily tied to sustenance of human life on earth. However, making this water available to the end user in most communities in Nigeria has been a challenge of utmost concern, considering that it has to be of safe quality [1] and affordable price. There is more government effort geared towards providing municipal potable water supply at subsidized rates while most rural communities in Nigeria [23] rely on rainwater, streams, rivers and wells or individually owned boreholes. Whereas the cost of obtaining water from rain, streams, rivers and wells is little or nothing compared to that of boreholes, its quality is usually far lower and less safe [19]. Therefore, for healthy consumption and quality sensitive uses in these rural communities, residents resort more to boreholes [3]. In urban areas where potable water supply is not sufficient or efficient, residents also largely resort to boreholes. Irregular pricing mechanism has been employed by private water supply utilities. Therefore, there is need to develop an appropriate pricing model for commercial community water supply. Various pricing models have been developed and proposed for water supply, based on different principles [10]. An appropriate pricing model is expected to provide an end-user friendly water tariff (utility rates) with an attendant positive cost-benefit implication [21]. Pricing models for water supply have been widely based on two broad considerations which are the average cost and marginal cost of water supply [15]. There are other general models referred to as partial equilibrium and general equilibrium which are based on effects of policy on a particular sector as against all sectors of an economy respectively [11]. These models can be referred to as the conventional water pricing models. The water pricing models based on average and marginal costs are referred to as second-best and first-best water pricing respectively [15]. The marginal cost pricing or first-best water pricing has been more popularly favoured in literary works over the average cost pricing or second-best water pricing 
due to the former's maximization of social welfare (i.e. most end-user friendly and conservation driven pricing) [8]. The marginal cost pricing is represented with the mathematical model [8] as follows,

$$
\mathrm{P}=\frac{\partial C(Q)}{\partial Q}+\lambda
$$

where $\lambda$ is marginal shadow price of water and $\mathrm{Q}$ is the volume of water produced by a water utility (e.g. borehole, state water works). The shadow price is only positive when withdrawals of water cause changes in the environment, or when there is water scarcity [8]. However, due to deficient revenue recovery of the utility in operation, criticisms have led to water utilities adopting the average cost prizing model [8] given as,

$$
\mathrm{P}=\frac{\partial C(Q)}{\partial Q}
$$

Under a budget constraint for a water utility, the average cost prizing model has been modified for maximal economic welfare, to give the expression [8] as,

$$
\frac{P-\partial C(Q) / \partial Q}{P}=\frac{\mu}{1+\mu} \times \frac{1}{\varepsilon}
$$

where $\varepsilon$ is price elasticity of the water demand and the term $\mu /(1+\mu)$ stands for budget constraint cost. Equation 3 is known as the Ramsey-Boiteux pricing model [8]. For this modified model to be effectively implemented, a total knowledge of marginal-cost and price elasticity is required [8].

On the other hand, there are more recent conceptual approaches to water pricing. These conceptual approaches vary from a more holistic, complex and integrated framework such as Nirvana Concepts' Integrated Water Resource Management (IWRM), to a more simplistic one such as Narratives and to the core political mechanism of Policy Formulation and Reforms [17]. These conceptual approaches can be referred to as organizational models. The IWRM concept is seen as a framework that facilitates the coordinated development and management of water, land and attendant resources, so as to optimize the resultant economic and social welfare in an equitable fashion. This is such that the sustainability of vital ecosystems is not hampered [9]. The Narratives concept bothers on a simplified interpretation of reality and is based on rationalizing physical/social phenomena. It actualizes this by organizing daily experiences and beliefs obtained from social interactions (e.g. surveys) with logical correlations, which thus result in opinions on what is preferable and what is not [17]. The third concept of Policy framework, whether formulation (development intervention) or reforms, deals with a more politically centered and driven process informed by experience, approved by experts and institutions of renown, and believed to greatly reduce risks [17]. These concepts on a closer look can be seen to be adopting or incorporating one or more of the earlier broad considerations and may be adapted to bear modifications to these considerations or their combinations as suffices for a prevalent water supply situation. Whereas all these models might meet up in addressing certain key water supply issues, they also fall short in other sensitive areas, which can be attributed to inherent, systemic or localized factors such as political dynamics, socioeconomic indices among others [4][7][13][14][16][26]. While policy and Nirvana frameworks are prone to hijack by dominant interests, imbalance in power play and inequity in genuine stakeholder participation within a society [4][13][14][26], Narratives framework on the other hand often has limited success to more narrow contexts and niches but poses uncertainty for an all-inclusive scope [7][16]. Being that average cost prizing, general equilibrium, IWRM and policy models are more inclined to economic welfare maximization while marginal cost pricing and Narratives models are more inclined to social welfare maximization, it behoves the water management societies and epistemic community to adapt an appropriate water pricing model that balances both maximization concerns, whether in a localized or generalized context as may be more feasible.

However, proposing a suitable water pricing in simplicity can either be based on a criterion of the unit cost of water production, which models that are more inclined to economic welfare maximization are more concerned about, or the willingness of end users/consumers to pay, which models that are more inclined to social welfare maximization are more concerned about. Irrespective of whichever concern is considered, data obtained from field surveys can be analyzed using fundamental statistical tools. The mean price for the price-frequency distribution can be computed using equation,

$$
\mu=\Sigma \mathrm{FX} / \Sigma \mathrm{F}
$$

where $\mu$ is the mean price for a litre of borehole water in naira, $\mathrm{X}$ is the classmark while $\mathrm{F}$ is the frequency of the classmark.

The median price for the price-frequency distribution is computed from equation, 


$$
\lambda=\mathrm{L}_{\mathrm{m}}+\left[\left(0.5 \Sigma \mathrm{F}-\mathrm{C}_{\mathrm{b}}\right) / \mathrm{F}_{\mathrm{m}}\right] \mathrm{C}_{\mathrm{m}}
$$

where $\lambda$ is the median price for a litre of borehole water, $\mathrm{L}_{\mathrm{m}}$ is the lower class boundary of the median class, $\mathrm{F}_{\mathrm{m}}$ is the frequency of the median class, $C_{b}$ is the cumulative frequency before the median class and $C_{m}$ is the class size of the median class.

The modal price for the price-frequency distribution is given by equation,

$$
\varnothing=\mathrm{L}_{\mathrm{o}}+\left[\left(\mathrm{f}_{\mathrm{o}}-\mathrm{f}_{\mathrm{b}}\right) /\left(2 \mathrm{f}_{\mathrm{o}}-\mathrm{f}_{\mathrm{a}}-\mathrm{f}_{\mathrm{b}}\right)\right] \mathrm{C}_{\mathrm{o}}
$$

where $\varnothing$ is the modal price for a litre of borehole water, $L_{o}$ is the lower class boundary of the modal class, $f_{o}$ is the frequency of the modal class, $\mathrm{f}_{\mathrm{a}}$ is the frequency after the modal class, $\mathrm{f}_{\mathrm{b}}$ is the frequency before the modal class and $\mathrm{C}_{\mathrm{o}}$ is the class size of the modal class.

The standard deviation for the price-frequency distribution is obtained from equation,

$$
\sigma=\left[\Sigma \mathrm{F}(\mathrm{X}-\mu)^{2} / \Sigma \mathrm{F}-1\right]^{1 / 2}
$$

where $\sigma$ is the standard deviation for the set of pricing data presented in Table 1 and every other parameter maintains its initial meaning.

Considering Nigeria as a case study, the following assertions can hold generally true throughout the country:

i.) though the urban areas may fare a little better than the rural ones in Nigeria, the government effort in portable water supply is largely deficient, unstable and unsustainable, whether for the urban or rural communities.

ii.) consequently, the larger population of Nigerians now resort to boreholes for a best alternative access to "pipe-borne" portable water.

iii.) irrespective of geographic location, socio-cultural, socio-political and socio-economic variations from one community to another, these are negligible to cause a significant difference in the results obtained for one community and another.

\section{Materials and Methods}

The research adopted the philosophical worldview of Advocacy/Participatory/idealism [5][22]. The use of survey was employed to obtain primary data which was considered for a quantitative analysis [5][22]. The survey only considered the willingness to pay rather than the unit cost of water production as its criterion and was achieved by means of offline questionnaires. The research design is exploratory and descriptive [18], using statistical approach of quantitative analysis with frequency and percentage, mean, median, mode and standard deviation being determined for one litre (1ltr) prices of borehole water. The findings are presented in tables and on bar charts. A target population of nine (9) communities spread across six states (Anambra, Ebonyi, Imo, Bayelsa, Delta and Rivers) within the South-south and South-east geo-political zones of Nigeria. The sample space was determined by age as individuals within the bracket of seventeen (17) years and sixty-six (66) years.

Basic assumptions were made as follows:

a.) water supply needs and challenges are relatively homogenous for almost and if not all communities within Nigeria.

b.) any result obtained for one community can be superimposed over another because all resource allocation and policy shortfalls from the relevant administrative bodies cut across board as well as economic performance indices are very similar across board.

In view of these assumptions, all the data collected were analyzed monolithically, at least for easy and concise presentation in a remote sense. A total of one hundred questionnaires were collected in correspondence with the target respondents within the sample space, thus giving a sample size of one hundred persons. For appropriate statistical analysis to be achieved, the chosen sample space was further divided into ten (10) age sub-groups of five (5) members each. The test quantity of water (independent variable) was chosen to be twenty-five litres (25ltrs) to be purchased from a borehole utility. The price to be paid for it (dependent variable) as deemed appropriate was supplied by the respondent (end user). The responses were classified according to age, sex, nationality, religion and social status in order to observe their effects (secondary independent variables) on the view of people towards water tariff or an appropriate water price. The research model is tailored after the marginal cost pricing and narratives model because it is more skewed towards a sociological dimension and is more centered on social welfare maximization. However, this research also made an adjustment to the pricing model obtained in order to make up for revenue recovery on the part of the utility for its sustainability and thereby achieve economic welfare maximization as well. This final modified model is what is proposed as an appropriate pricing model for community water supply. The mean price for each of the aspects characterized by secondary independent variables was first determined and then the overall average price was also determined before the modification was made to achieve the final model.

The unit prices for 11 tr of water were calculated from the prices for 25lts using equation, 


$$
\mathrm{p}(\mathrm{N})=\mathrm{P} / 25
$$

where $\mathrm{p}$ is the price per litre in naira and $\mathrm{P}$ is the respondent's price in naira too for the test quantity of 251 trs.

The mean, median, modal prices and also the standard deviation for 1ltr were computed using the Equations 4, 5, 6 and 7 respectively, already given in the previous segment.

\section{Results}

Table 1 shows the classes of ranges of prices offered by the respondents for the test quantity of 251 trs and their conversion to price range class equivalents for the standard unit quantity of 11 tr. It also presents the 11 tr price range class boundaries.

Table 1: Price-frequency distribution for 25 litres of water and its 1 litre equivalent

\begin{tabular}{|c|c|c|c|c|c|c|c|}
\hline $\begin{array}{l}\text { Survey } \\
\text { Prices } \\
\text { for } 25 \\
\text { Litres of } \\
\text { water } \\
\text { ( } ¥) \\
\end{array}$ & $\begin{array}{l}\text { Class Limit } \\
\text { for 1Litre of } \\
\text { Water } \\
\text { (\#) }\end{array}$ & $\begin{array}{l}\text { Class } \\
\text { Boundary } \\
\text { (\#) } \\
\end{array}$ & $\begin{array}{l}\text { Classmark, } \\
\mathbf{X} \\
\text { (¥) }\end{array}$ & $\begin{array}{l}\text { Frequency, } \\
\text { F }\end{array}$ & Percentage, \% & FX & $\mathbf{F}(\mathbf{X}-\mu)^{2}$ \\
\hline $1-2$ & $0.040-0.080$ & $0.035-0.085$ & 0.06 & 4 & 4 & 0.24 & 0.462 \\
\hline $3-4$ & $0.120-0.160$ & $0.115-0.165$ & 0.14 & 5 & 5 & 0.7 & 0.338 \\
\hline $5-6$ & $0.200-0.240$ & $0.195-0.245$ & 0.22 & 8 & 8 & 1.76 & 0.259 \\
\hline $7-8$ & $0.280-0.320$ & $0.275-0.325$ & 0.3 & 22 & 22 & 6.6 & 0.22 \\
\hline $9-10$ & $0.360-0.400$ & $0.355-0.405$ & 0.38 & 16 & 16 & 6.08 & 0.006 \\
\hline $11-12$ & $0.440-0.480$ & $0.435-0.485$ & 0.46 & 18 & 18 & 8.28 & 0.065 \\
\hline 13-14 & $0.520-0.560$ & $0.515-0.565$ & 0.54 & 16 & 16 & 8.64 & 0.314 \\
\hline $15-20$ & $0.600-0.800$ & $0.595-0.805$ & 0.7 & 11 & 11 & 7.7 & 0.99 \\
\hline \multicolumn{4}{|l|}{ SUM } & 100 & 100 & 40 & 2.65 \\
\hline
\end{tabular}

For the $1 \mathrm{~L}$ equivalent of $25 \mathrm{~L}$ of water, the median class is $(0.355-0.405)$ and the modal class is $(0.275-0.325)$. Using Equation 5 , the mean price was computed to be $¥ 0.400$. From Equation 6, the median price was computed to be $\$ 0.389$. The modal price was computed to be 0.310 from Equation 7 while the standard deviation was computed to be $\$ 0.163$ from Equation 8 . The pricefrequency distribution is illustrated in Figure 1.

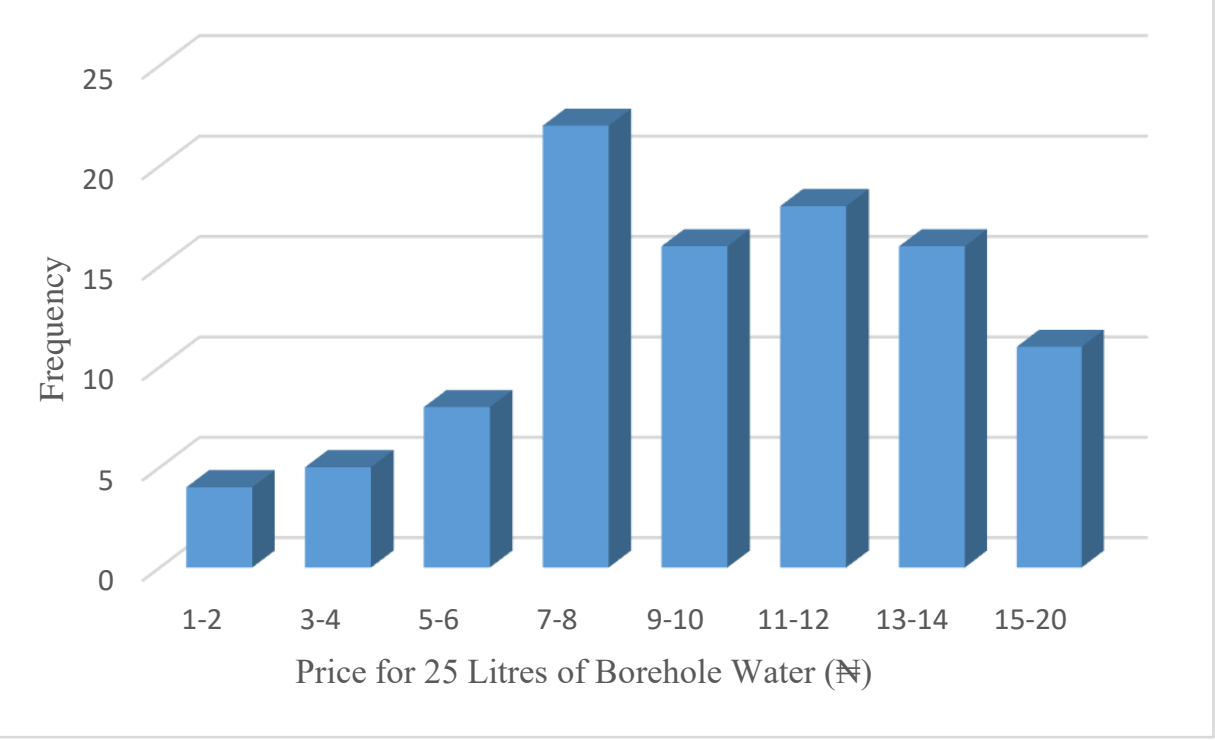


Fig.1: Price-frequency distribution chart

The graph shows that the highest number of respondents opted to pay a price within the range of $\$ 7$ to while the least opted for the range of $\$ 1$ to $\$ 2$ for the test quantity of 25 litres of borehole water.

Table 2 shows the variation of 1 litre price with respect to the age of respondents.

Table 2: Price-age distribution for 1 litre of water

\begin{tabular}{|c|c|c|c|c|c|}
\hline $\begin{array}{l}\text { Age } \\
\text { Group }\end{array}$ & \begin{tabular}{|l|} 
Age \\
Group \\
Price, X \\
(\#) \\
\end{tabular} & $\begin{array}{l}\text { Frequency, } \\
\text { F }\end{array}$ & $\begin{array}{l}\text { Percentage, } \\
\%\end{array}$ & $\begin{array}{l}\text { FX } \\
\text { (\#) }\end{array}$ & $\begin{array}{l}F(X-\mu)^{2} \\
(\#)^{2}\end{array}$ \\
\hline $17-21$ & 0.25 & 12 & 12 & 3.00 & 0.277 \\
\hline $22-26$ & 0.36 & 10 & 10 & 3.6 & 0.018 \\
\hline $27-31$ & 0.39 & 8 & 8 & 3.12 & 0.0012 \\
\hline $32-36$ & 0.41 & 7 & 7 & 2.87 & 0.0004 \\
\hline $37-41$ & 0.43 & 13 & 13 & 5.59 & 0.0102 \\
\hline $42-46$ & 0.51 & 11 & 11 & 5.61 & 0.1283 \\
\hline $47-51$ & 0.5 & 10 & 10 & 5.03 & 0.096 \\
\hline $52-56$ & 0.45 & 9 & 9 & 4.05 & 0.0207 \\
\hline $57-61$ & 0.38 & 12 & 12 & 4.56 & 0.0058 \\
\hline $62-66$ & 0.34 & 8 & 8 & 2.72 & 0.0308 \\
\hline SUM & & 100 & 100 & 40.15 & 0.59 \\
\hline
\end{tabular}

The mean price for water based on the age of respondents was obtained to be $\$ 0.402$ per litre while the standard deviation was obtained as $\$ 0.077$.

From Table 2, it can be seen that the age group that offered the highest price for a litre of water is $42-46$ years, who likely are the most economically viable individuals within the sample space. The age group that offered the least price is 17-21 years, who are most likely the least economically viable individuals within the same sample space. It can be summarized that the extreme age groups of very young and advanced respondents both offered much lower prices than the middle age groups likely because at those extreme ages, individuals are usually at a much lower economic capacity than at the middle ages of life.

The mean water price for the gender-based frequency distribution was obtained to be $\$ 0.400$ per litre while the standard deviation was obtained to be $¥ 0.019$. The female respondents offered to pay a higher price for a litre of borehole water than their male counterparts. This may be due to the fact that Nigerian women bear more water burden. Therefore, in order to relieve themselves of stress associated with searching long distances for water, they would rather offer more to get it close by and maybe because they are not the financiers of the water procurement. However, that the women were willing to pay an extra $10 \%$ of what the men offered is quite significant.

The mean price of water based on nationality of respondents was obtained to be $\$ 0.400$ per litre while the standard deviation was \$0.036. The non-Nigerian respondents favoured paying a higher price for a litre of water than their Nigerian counterparts probably because they are used to paying for water in their home countries. They also appear to be more economically viable within the sample size.

The mean water price for the religion based respondents was obtained to be $\$ 0.400$ per litre of water the standard deviation was \$0.040. The Christian respondents were more favourably disposed to paying a higher price per litre of water than their non-Christian counterparts because they are more liberal, more economically empowered and also because of their faith convictions. It is likely that 
other religions are practiced in welfarist states while Christianity is practiced mostly in capitalist states. However, it is worthy to note that the target population was situated in a study area that is predominantly Christian.

For water price based on social status of respondents, the mean was obtained to be $¥ 0.400$ per litre of water while the standard deviation was obtained to be $¥ 0.113$. The working class respondents offered to pay a higher price per litre of water than their nonworking counterparts. This would be most likely because they possess economic power much greater than that of their unemployed counterparts. Money empowers the capacity to pay, the propensity to buy and is the guarantee for effective demand. Figure 3 illustrates the distribution of price per litre of water against gender, nationality, religion and social status.



Fig.3: Price-aspect (class) distribution chart

Table 3 presents the general numerical result from which the overall average or mean price per litre of borehole water and the sample standard deviation were calculated.

Table 3: General numerical result table.

\begin{tabular}{|c|c|c|c|c|c|c|c|}
\hline SN & Aspect & Class & $\begin{array}{l}\text { Class } \\
\text { Price, } \\
\text { X (\#) }\end{array}$ & $\begin{array}{l}\text { Frequency, } \\
\text { F }\end{array}$ & $\begin{array}{l}\text { Percentage, } \\
\%\end{array}$ & FX & $\begin{array}{l}\mathrm{F}(\mathrm{X}-\mu)^{2} \\
(\#)^{2}\end{array}$ \\
\hline 1 & Price-Freq. & & 0.4 & 100 & 100 & 40 & 0 \\
\hline 2 & Price-Age & & 0.402 & 100 & 100 & 40.2 & 0.0004 \\
\hline \multirow[t]{2}{*}{3} & \multirow[t]{2}{*}{ Price-Gender } & Male & 0.38 & 47 & 47 & 17.86 & 0.0188 \\
\hline & & Female & 0.418 & 53 & 53 & 22.154 & 0.0172 \\
\hline \multirow[t]{2}{*}{4} & \multirow{2}{*}{$\begin{array}{l}\text { Price- } \\
\text { Nationality }\end{array}$} & Nigerians & 0.39 & 93 & 93 & 36.27 & 0.0093 \\
\hline & & Non-Nigerians & 0.53 & 7 & 7 & 3.731 & 0.1238 \\
\hline \multirow[t]{2}{*}{5} & \multirow[t]{2}{*}{ Price-Religion } & Christians & 0.41 & 94 & 94 & 38.54 & 0.0094 \\
\hline & & Non-Christians & 0.243 & 6 & 6 & 1.458 & 0.1479 \\
\hline \multirow[t]{2}{*}{6} & \multirow{2}{*}{$\begin{array}{l}\text { Price-Social } \\
\text { Status }\end{array}$} & Working Class & 0.527 & 44 & 44 & 23.188 & 0.7097 \\
\hline & & $\begin{array}{l}\text { Non-Working } \\
\text { Class }\end{array}$ & 0.3 & 56 & 56 & 16.8 & 0.56 \\
\hline \multicolumn{4}{|c|}{ SUM } & 600 & & 240.201 & 1.5965 \\
\hline
\end{tabular}

Using Equation 4, the overall average price for a litre of borehole water was calculated to be $¥ 0.400$. The sample standard deviation was calculated using equation 8 and was obtained to be $\$ 0.054$. 
From the general numerical result in Table 3, it can be seen that the two extreme class averages farthest from the overall average of the sample are $\$ 0.243$ and $¥ 0.533$. The difference between the sample overall average of $\$ 0.400$ and the lowest class average of $\$ 0.243$ does not exceed three standard deviations $(-3 \sigma)$ on the negative axis while the difference between the sample overall average and the highest class average of $\$ 0.533$ lies within three standard deviations $(3 \sigma)$ on the positive axis [27]. This proves that the set of data obtained in the survey give the normal or Gaussian distribution [12] which is okay.

Having obtained the overall average price for a litre of borehole water, using the presented sample, to be $\$ 0.400$, a modification was made to account for deficiency in revenue recovery and ensure that economic welfare maximization is met concurrently with social welfare maximization. This was achieved by incorporating an access or service charge factor [21] into the unit water price. To practically do this, the cost of supplying water including operating costs, capital expenditure for future augmentation, a return of capital (funding of depreciation) and a return on investment [21] for the utility (borehole) is obtained for a month. The average water provision capacity in a month is obtained for the utility also. Let the service charge for a month be $\mathbf{y}$ in naira and the average water provision capacity in a month be $\mathbf{q}$ in litres, the access or service charge factor, $\mathbf{z}$ in naira per litre will be given by the Equation 9 .

$$
\mathrm{z}(\mathrm{N} / \mathrm{ltr})=\mathrm{y} / \mathrm{q}
$$

With this factor being incorporated in the overall average price for a litre of borehole water, the following expression of Equation 10 is obtained.

$$
\mathrm{p}=0.4+\mathrm{z}
$$

where $\mathbf{p}$ is the final consolidated price per litre of water from a commercial source.

\section{Conclusion and Recommendations}

An appropriate price for community water supply was established based on a modified model incorporating the obtained respondents' willingness to pay and a unit service charge to be worked out by the commercial source agreeably under some sort of public harmonized regulatory arrangement. The model is given as the equation, $\mathbf{p}=\mathbf{0 . 4}+\mathbf{z}$ and takes care of both social as well as economic welfare maximizations. The standard deviation of the sample showed that the results follow a normal distribution pattern. Therefore, the resultant pricing model can be applied over the entire target population and extended to other populations beyond it, within the Nigerian enclave. Also, government public utilities can adopt this model for sustainability and even global competitiveness.

\section{References}

1. Agbazue VE (2008) The Chemist and Self Employment. Book of Proceeding of the International Conference of the Chemical Society of Nigeria held in Effurun, Delta State.

2. Akpoborie T, Egbo SHO, Ebenuwa CC, Emeshili EM (2008) Comparative Study of the Satchet Water in Asaba Metropolis, South-south, Nigeria. Book of Proceeding of the International Conference of the Chemical Society of Nigeria held in Effurun, Delta State.

3. Akpoveta OV, Okoh BE, Osakwe SA (2011) Quality Assessment of Borehole Water used in the vicinities of Benin, Edo State and Agbor, Delta State of Nigeria. Current Research in Chemistry, 3:62-69.

4. Connell D (2006) Water Politics in the Murray-Darling Basin. Leichhardt, NSW, Australia: The Federation Press.

5. Cresswell (2009) Research Design: Qualitative, Quantitative and Mixed Methods Approaches, Thousand Oaks, CA: Sage.

6. Denton JA (1990) Society and the Official World: A Reintroduction to Sociology. Dix Hills, NY: General Hall. P.17. ISBN 0-930390-94-6.

7. Easterly W (2001) The elusive quest for growth: Economist's adventures and misadventures in the tropics. Cambridge: MIT Press.

8. Garcia S, Reynaud A (2004) Estimating the benefits of efficient water pricing in France. Resour. Energy Econ. 26(1):1-25.

9. Global Water Partnership (GWP) (2000) Integrated Water Resources Management. TAC Background Paper No.4. Stockholm: Global Water Partnership. 
10. Johansson RC (2000) Pricing Irrigation Water: A literature survey. World Bank Policy Res. Working Paper 2449.

11. Johansson RC, Tsur Y, Roe TL, Doukkali R, Dinar A (2002) Pricing Irrigation Water: A Review of Theory and Practice. Water Pol. 4(2):173-199.

12. Kirkwood BR, Stern JAC (2003) Essential Medical Statistics. Blackwell Science Ltd.

13. Merrey DJ, Van Koppen B (2007) Balancing equity, productivity and sustainability in a waterscarce river basin: The case of the Olifants river basin in South Africa. IWMI, Colombo: Comprehensive Assessment of Water Management in Agriculture. Draft.

14. Miller F, Hirsh P (2003) Civil Society and Internationalized River Basin Management. Working Paper No.7. Sydney: Australian Mekong Resource Centre, University of Sydney.

15. Mohayidin G, Attari J, Sadeghi A, Hussein MA (2009) Review of Water Pricing Theories and Related Models. African Journal of Agricultural Research Vol.4(13), pp.1536-1544. ISSN 1991-637x, available online at http://www.academicjournals.org/AJAR

16. Molle F, Berkoff J (Eds) (2007a) Irrigation Water Pricing: The gap between theory and practice. Comprehensive Assessment of Water Management in Agriculture. Wallingford, UK: CABI.

17. Molle F (2008) Nirvana Concepts, Narratives and Policy Models: Insight from the Water Sector. Water Alternatives 1(1):131-156.

18. Monroe College. Exploratory, Descriptive and Causal Research Design [Online] Available at http://www.monroecollege.edu/academicresources/ebooks/9781111532406 Lores p01 ch03.pdf (Accessed: April 2014)

19. Odiba JO, Matthew OA, Raphael O, Gary Y, Gideon AS (2014) Assessment of Water Quality Index of Borehole and Well Water in Wukari Town, Taraba State, Nigeria. Journal of Environment and Earth Science Vol.4(5). ISSN 2224-3216 (Paper) ISSN 2225-0948 (Online), published by IISTE, 2014 (https://www.iiste.org)

20. Osunkiyesi AA (2012) Physicochemical analysis of Ogun River (water samples) within two locations (Akin-Olugbade and Lafenwa) in Abeokuta, Ogun State. IOSR Journal of Applied Chemistry. 1(4):24-27.

21. Queensland Water Directorate (2018) Water Pricing. https://www.qldwater.com.au > waterpricing (retrieved November 2018)

22. Saunders, Lewis and Thornhill (2009) Research Methods for Business Students, 5th Edition, (CMark Saunders, Philip Lewis and Adrian Thornhill 2009.

23. Shittu OB, Olaitan JO, Amusa T (2008) Physico-chemical analysis of water used for drinking and swimming purposes in Abeokuta, Nigeria. African Journal of Biomedical Research. 11:285-290.

24. Silderberg MS (2003) Higher Education Chemistry. The Molecular Nature of Matter and Change, Mc Graw Hill.

25. USAID (2007a) What is Integrated Water Resources Management? www.usaid.gov/ourwork/environment/water/what_is_iwrm.html (accessed in March 2007)

26. Wester P, Warner J (2002) River basin management reconsidered in Turton A and Henwood R (Eds), Hydropolitics in the developing world: A Southern African perspective. Pretoria: African Water Issues Research Unit.

27. What is Standard Deviation? Pristine. Retrieved 2011-10-29.

WWW.scirj.org

(C) 2020, Scientific Research Journal

http://dx.doi.org/10.31364/SCIRJ/v8.i3.2020.P0320755 
28. https://www.businessinsider.com (Dina Spector, Mar.8, 2018, 5:59AM ET)

www.scirj.org

(C) 2020, Scientific Research Journal 